February 2005

\title{
Genetic consequences of tropical second-growth forest regeneration
}

\section{Uzay U. Sezen}

University of Connecticut, uzay.sezen@huskymail.uconn.edu

Robin L. Chazdon

University of Connecticut, robin.chazdon@uconn.edu

Kent E. Holsinger

University of Connecticut, kent.holsinger@uconn.edu

Follow this and additional works at: https://opencommons.uconn.edu/eeb_articles

\section{Recommended Citation}

Sezen, Uzay U.; Chazdon, Robin L.; and Holsinger, Kent E., "Genetic consequences of tropical second-growth forest regeneration" (2005). EEB Articles. 2.

https://opencommons.uconn.edu/eeb_articles/2 


\title{
Genetic Consequences of Tropical Second-growth Forest Regeneration
}

\author{
Uzay U. Sezen*, Robin L. Chazdon \& Kent E. Holsinger \\ *Department of Ecology and Evolutionary Biology, University of Connecticut, Storrs, \\ 06269-3043, CT.
}

To whom correspondence should be addressed. E-mail: uzay.sezen@huskymail.uconn.edu

Despite a long history of international and local efforts, old-growth tropical forests are still being cleared. Today, second-growth forests cover more area than old-growth forests in many tropical countries (1). Yet we know little about the genetic composition of founding populations in second-growth forests (2). Parentage analysis can reveal patterns of gene flow through pollen and seed dispersal, providing accurate information about the sources of founding populations (3-5). Here, we assess parentage of founders of the abundant canopy palm Iriartea deltoidea in a second-growth forest in Costa Rica.

Iriartea is an abundant canopy palm with a wide geographic distribution in Neotropical forests $(6)$. Its monoecious flowers are pollinated by stingless bees (Trigona spp., Melipona spp.) and now by honey bees (Apis spp.). Seeds are dispersed by a variety of birds and mammals including toucans, white-faced monkeys, peccaries, tapir, and several species of rodents. This shade-tolerant species shows broad representation of all size classes in mature forests.

We analyzed the entire founder generation of 130 flowering and fruiting trees in a 24-yr old second-growth forest adjacent to old-growth forest at La Selva Biological Field Station in Costa Rica (7). The study area is a 300 x $1000 \mathrm{~m}$ protected area covering 20 ha 
of second-growth and 10 ha of adjacent old-growth forest, protected since 1981. Iriartea depends on newly dispersed seed to recolonize second-growth forests. In our study area, all potential seed sources reside in old-growth forest. We define the founder generation as the first generation derived from seeds that colonized abandoned pasture. Monitoring data obtained from a permanent sample plot show that Iriartea reached reproductive maturity in as little as 20 years in this second-growth forest.

Our parentage analysis with 141 Amplified Fragment Length Polymorphism (AFLP) loci revealed high levels of reproductive dominance among parents of the source population (7). Among 66 old-growth forest trees, only 2 contributed $56 \%$ of the genes to the second-growth founder population, 23 contributed the remaining $44 \%$, and 41 had no offspring.

Average seed dispersal distance greatly exceeded that of pollen dispersal. The median seed dispersal distance was $270 \mathrm{~m}$, while the longest (minimum) dispersal distance we detected was more than $875 \mathrm{~m}$ (7). Maximum pollen movement was less than $220 \mathrm{~m}$. The median pollination distance was $100 \mathrm{~m}$, and $50 \%$ of the pollination events within $120 \mathrm{~m}$ distance class corresponded to pollen movement between the two reproductively dominant trees.

Reproductive dominance of a few old-growth parents had strong genetic consequences in the second-growth forest. Genetic diversity in second-growth founders was significantly lower than in adjacent old-growth trees (mean dissimilarity among individuals was 0.58 in second-growth and 0.73 in old-growth; Tanimoto`s D (7) (Figure 1). Patch sizes of similar genotypes were larger in second-growth (125 m) than in oldgrowth $(96 \mathrm{~m})$. 
Reproductive dominance may be especially common in early successional forests. We do not know why two trees in our study show such extreme reproductive dominance. Even in this best-case scenario of forest regeneration, where numerous and diverse seed sources remain in a protected, adjacent, old-growth forest, the animal disperser community is intact, and there are no physical or ecological barriers to dispersal, more than half of the founding Iriartea population were full siblings. Dominance patterns may be even more skewed in cases where the pool of parent trees is more restricted in size or genetic diversity.

Similar colonization patterns and genetic consequences may apply to a broad suite of tree and palm species that colonize young second-growth and persist as shade-tolerant species in later successional stages. Most studies of gene flow in plants have concentrated on pollen mediated gene flow and male reproductive success $(3,4)$. Colonization of second-growth depends on seed dispersal; here we demonstrate that dispersal can contribute more to total gene flow than pollen movement during tropical forest succession. We expect dispersal and (to a lesser extent) pollination distances to diminish as local seed production increases during succession.

Reduced genetic diversity of the founder population will likely persist in later generations as closely related founders contribute an increasing fraction of seedlings. Our results on the founders suggest that tree populations in second-growth forests will require continuous gene flow over successive generations to restore genetic diversity to levels currently observed in local old-growth forests.

\section{References and Notes}


1. FAO Global Forest Resource Assessment 2000 Main Report. FAO Forestry Paper 140. FAO, Rome (2001).

2. M. Cespedes, V. Gutierrez, N.M. Holbrook, O.J. Rocha. Mol. Ecol. 12, 3201 (2003).

3. J.D. Nason, A.E. Herre, J.L. Hamrick. Nature 391, 685 (1998).

4. M.R. Chase, C. Moller, R. Kesseli, K.S. Bawa. Nature 383, 398 (1996).

5. P.R. Aldrich, J.L. Hamrick. Science 281, 103 (1998).

6. A. Henderson. Arecaceae. Part1: Introduction and the Iriarteinae. Flora Neotrop. Monogr. 53, (1990).

7. Materials and Methods are available as supporting material online on Science Online.

8. This project was funded by the Andrew W. Mellon Foundation. 


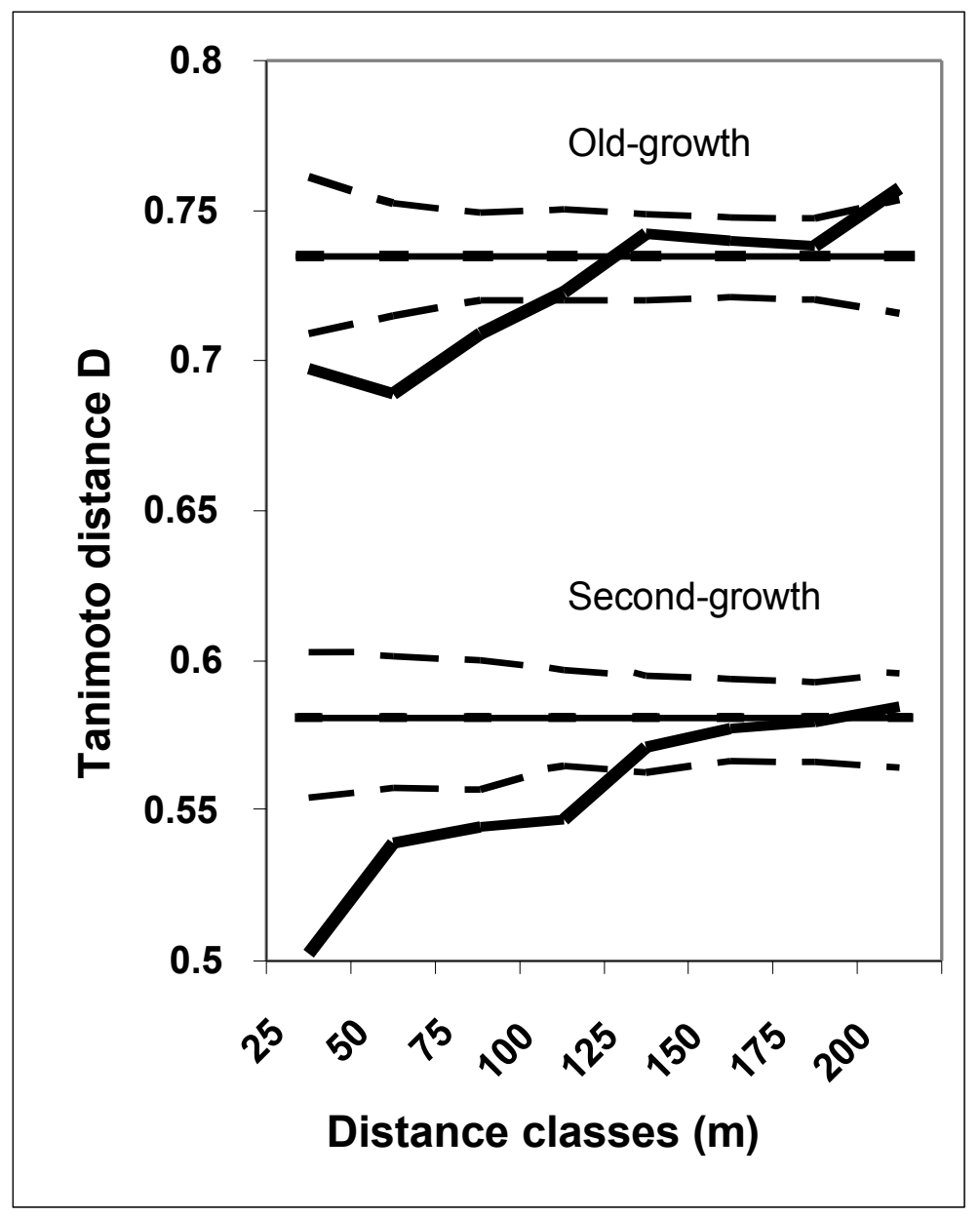

Fig. 1 Spatial autocorrelation distogram of mature trees in both forests using Tanimoto`s D. Confidence intervals (95\%) for no spatial structure are indicated by dashed lines. Overall mean of genetic distances for both forests are shown as flat lines as a reference for random spatial structure. 